\title{
Assessment of Variability of Aromatic Rice Using Agro-Morphological Characterization
}

\author{
Nidhi Kujur, Sandeep Bhandarker, Yogita Shrivas and Alice Tirkey*
}

Department of Genetics and Plant Breeding, Indira Gandhi Krishi Vishwavidyalaya, College of Agriculture, Raipur- 492012, Chhattisgarh, India

*Corresponding author

\section{A B S T R A C T}

\begin{tabular}{|l|}
\hline K e y w o r d s \\
Aromatic rice, \\
$\begin{array}{l}\text { Morphological } \\
\text { characterization, } \\
\text { Qualitative characters. }\end{array}$ \\
\hline Article Info \\
\hline $\begin{array}{l}\text { Accepted: } \\
\text { 15 September } 2017 \\
\text { Available Online: } \\
10 \text { November } 2017\end{array}$ \\
\hline
\end{tabular}

\section{Introduction}

Rice (Oryza sativa L. $2 \mathrm{n}=24$ ) is one of the most important cereal crop that has been referred as "Global Grain" because of its use as prime staple food in about 100 countries of the world. In world, rice has occupied an area of 160.6 million hectares, with a total production of 738.20 million tones and productivity $3424.41 \mathrm{~kg} / \mathrm{ha}$ (FAO, 2015). India being the second largest producer of rice after china, has production of 105.48 million tones with productivity $3020 \mathrm{~kg} / \mathrm{ha}$ (FAO, 2015). Central India is well known for its native wealth of rice genetic resources and among these the large number of indigenous short grained, scented varieties cultivated in different pocket of Madhya Pradesh and Chhattisgarh state. Chhattisgarh popularly known as "Rice Bowl of India" occupies an area around 37.73 lakh hectares with the production of 60.28 lakh tones and productivity $1597 \mathrm{~kg} / \mathrm{ha}$ (Anon, 2015).

The Indian aromatic rice, often called Basmati is nature's gift to the sub-continent and human kind at large (Ahuja et al., 1995). With growing demand for aromatic rice in international market high emphasis was placed till now on improvement of basmati types. The improvement of indigenous small and medium grained aromatic rice, which possess outstanding quality like aroma, kernel elongation after cooking and taste were somewhat neglected as they lacked export value. Almost every state of the country has 
its own set of aromatic rice that performs well in native areas. Aroma and taste of short grained aromatic rice specially Badshahbhog and Dubraj is known to be superior to Basmati types (Hossain et al., 2009).

The fine grain aromatic rice is considered high quality rice and fetch a high price in the national and international trade. However, yield per unit area of aromatic rice is very low due to tall plant habit and late maturity. So, broadening the genetic base of rice is an essential requirement for aromatic rice improvement programme.

Scented rice is very much liked to its unique aroma, grain dimension, cooking quality and palatability etc. Most of the information we have so far is about common varieties and our knowledge about aromatic rice is still incomplete. In every increasing global demand for aromatic rice has been noted in the recent times. Therefore, in this context an attempt is made to characterize a set of aromatic rice for different morphological and agronomic traits and to identify the variability available in the collection.

\section{Materials and Methods}

The present study was conducted using about 47 aromatic genotypes of rice were selected for this study including 3 popular checks viz., Kalanamak, Badshahbhog and Indira Sugandhit Dhan-1 in a Randomized Block Design (RBD) with two replications. Each genotype was grown in on plot size was $5 \mathrm{~m} \mathrm{X}$ $2 \mathrm{~m}$ with row to row distance was $20 \mathrm{~cm}$ and plant to plant distance was $15 \mathrm{~cm}$. These genotypes were received from DRR Hyderabad. The recommended agronomical practices were followed to raise good crop in the season.

Five random plants from each of the plot were chosen for recording 29 morphological and 11 agronomical characters. The studied were Coleoptile: colour, Basal leaf: sheath colour, Leaf: intensity of green colour, Leaf: anthocyanin colouration, Leaf sheath: anthocyanin colouration, Leaf sheath: intensity of anthocyanin colouration, Leaf: pubescence of blade surface, Leaf: auricles, Leaf: anthocyanin colouration of auricles, Leaf: collar, Leaf: anthocyanin colouration of collar, Leaf: ligule, Leaf: shape of ligule, Leaf: colour of ligule, Leaf: length of blade, Leaf: width of blade, Culm: attitude, Time of heading $(50 \%$ of plants with panicles), Flag leaf: attitude of blade, Spikelet: density of pubescence of lemma, Spikelet: colour of stigma, Stem: length, Stem: anthocyanin colouration of nodes, Stem: intensity of anthocyanin colouration of nodes, Stem: anthocyanin colouration of internodes, Panicle: length of main axis, Panicle: number effective tillers per plant, Lemma and palea: colour, Panicle: awns, Panicle: presence of secondary branching, Panicle: attitude of branches, Panicle: exsertion, Grain: weight of 1000 fully developed grains, Grain: length, Grain: width, Decorticated grain: length, Decorticated grain: width, Decorticated grain: colour and Decorticated grain: aroma. Frequency distribution was computed to categorize the accession into different classes.

\section{Results and Discussion}

\section{Morphological characterization}

Qualitative characters are important for plant description (Kurlovich, 1998) and mainly influenced by the consumers preference, socioeconomic scenario and natural selection (Hien et al., 2007).

Frequency distribution for 29 qualitative traits is depicted in Table 1 and its graphical representation of frequency distribution showed in Figure 1. Most of the morphological characters showed variation in 
different accessions except coleoptile: colour, Leaf: auricle, Leaf: anthocyanin colouration of auricles, Leaf: collar, Leaf: anthocyanin colouration of collar, Leaf: ligule, Panicle: presence of secondary branching, and decorticated grain: aroma.

A majority of accessions were found to possess Basal leaf: sheath colour $(97.87 \%$ green), Leaf: intensity of green colour (44.68\% light green), Leaf: anthocyanin colouration (85.10\% absent), Leaf sheath: anthocyanin colouration $(97.87 \%$ absent $)$, Leaf sheath: intensity of anthocyanin colouration $(97.87 \%$ very weak), Leaf: pubescence of blade surface $(40.42 \%$ medium), Leaf: shape of ligule ( $91.48 \%$ split), Leaf: colour of ligule ( $97.87 \%$ white), Culm: attitude $(61.70 \%$ semi erect), Flag leaf: attitude of blade $(80.85 \%$ semi erect $)$, Spikelet: density of pubescence of lemma (78.72\% absent), Spikelet: colour of stigma (95.74\% white), Stem: anthocyanin colouration of nodes ( $97.87 \%$ absent), Stem: intensity of anthocyanin colouration of nodes (97.87\% weak), Stem: anthocyanin colouration of internodes (97.87\% absent), Lemma and palea: colour (70.21\% straw), Panicle: awns (82.97\% absent), Panicle: attitude of branches $(78.72 \%$ semi erect to spreading), Panicle: exsertion $(74.46 \%$ well exserted) and decorticated grain: colour $(97.87 \%$ white). Some of the unique accessions with distinct features are presented in Table 2.

\section{Agronomical characterization}

Rice accessions were evaluated for 11 agronomical traits viz., Leaf: length of blade, Leaf: width of blade, time of $50 \%$ heading, Stem: length, Panicle: length of main axis, Panicle: number of effective tillers per plant, Grain: weight of 1000 fully developed grains, Grain: length, Grain: width, Decorticated grain: Length and Decorticated grain: width from five competitive plants of middle row of each entry.

\section{Leaf length $(\mathrm{cm})$}

Leaf length ranged from 31.02 to 57.68 with a mean performance of $43.65 \mathrm{~cm}$.

The maximum leaf length (57.68) recorded for HUR 1307 and minimum leaf length (31.02) was recorded for PAB 9527.

\section{Leaf width $(\mathrm{cm})$}

Leaf width ranged from 0.73 to 1.42 , with a mean performance of $0.95 \mathrm{~cm}$. The maximum leaf width (1.42) recorded for Indira Sugandhit dhan-1 and minimum leaf width (0.95) was recorded for CN1643-3.

\section{Days to $50 \%$ flowering}

Days to $50 \%$ flowering ranged from 76 to 125 days with a mean performance of 102 days. CR 2947-1-1-5 (125 days) recorded maximum days for $50 \%$ flowering, while CSAR 10210 required 76 days for $50 \%$ flowering.

\section{Plant height (cm)}

In experimental material plant height was ranged from 92.80 to $198.90 \mathrm{~cm}$ with a mean plant height of $126.15 \mathrm{~cm}$. The maximum plant height was recorded in Kalanamak (RC) $(198.90 \mathrm{~cm})$ and the minimum plant height $(92.80 \mathrm{~cm})$ was observed in R1656-1146-5513-1. Ali et al., (2000) have observed relatively greater range in plant height than the other characters. Plant height in rice is a complex character and is the end product of several genetically controlled factors called internodes (Cheema et al., 1987). Reduction in plant height may improve their resistance to lodging and reduce substantial yield losses associated with this trait (Abbasi et al., 1995). 
Table.1 Frequency distribution for morphological characters in rice

\begin{tabular}{|c|c|c|c|}
\hline S. No. & Characteristics & Colour pattern/ type & Frequency \\
\hline 1 & Coleoptile: colour & $\begin{array}{l}\text { colourless } \\
\text { green } \\
\text { purple }\end{array}$ & $\begin{array}{c}47 \\
\text { Nil } \\
\text { Nil }\end{array}$ \\
\hline 2 & Basal leaf: sheath colour & $\begin{array}{l}\text { green } \\
\text { light purple } \\
\text { purple lines } \\
\text { purple }\end{array}$ & $\begin{array}{c}46 \\
\text { Nil } \\
1 \\
\text { Nil }\end{array}$ \\
\hline 3 & Leaf: intensity of green colour & $\begin{array}{l}\text { light } \\
\text { medium } \\
\text { dark }\end{array}$ & $\begin{array}{l}21 \\
16 \\
10 \\
\end{array}$ \\
\hline 4 & Leaf: anthocyanin colouration & $\begin{array}{l}\text { absent } \\
\text { present }\end{array}$ & $\begin{array}{c}40 \\
7\end{array}$ \\
\hline 5 & Leaf : distribution of anthocyanin colouration & $\begin{array}{l}\text { on tips only } \\
\text { on margins only } \\
\text { in blotches only } \\
\text { uniform }\end{array}$ & $\begin{array}{c}7 \\
\text { Nil } \\
\text { Nil } \\
\text { Nil }\end{array}$ \\
\hline 6 & Leaf sheath: anthocyanin colouration & $\begin{array}{l}\text { absent } \\
\text { present }\end{array}$ & $\begin{array}{c}46 \\
1\end{array}$ \\
\hline 7 & $\begin{array}{l}\text { Leaf sheath : intensity of anthocyanin } \\
\text { colouration }\end{array}$ & $\begin{array}{l}\text { very weak } \\
\text { weak } \\
\text { medium } \\
\text { strong } \\
\text { very strong }\end{array}$ & $\begin{array}{c}46 \\
\text { Nil } \\
\text { Nil } \\
1 \\
\text { Nil }\end{array}$ \\
\hline 8 & Leaf: pubescence of blade surface & $\begin{array}{l}\text { absent } \\
\text { weak } \\
\text { medium } \\
\text { strong } \\
\text { very strong }\end{array}$ & $\begin{array}{c}\text { Nil } \\
17 \\
19 \\
11 \\
\text { Nil }\end{array}$ \\
\hline 9 & Leaf : auricles & $\begin{array}{l}\text { absent } \\
\text { present }\end{array}$ & $\begin{array}{c}47 \\
\text { Nil } \\
\end{array}$ \\
\hline 10 & Leaf: anthocyanin colouration of auricles & $\begin{array}{l}\text { colourless } \\
\text { light purple } \\
\text { purple } \\
\end{array}$ & $\begin{array}{c}47 \\
\text { Nil } \\
\text { Nil } \\
\end{array}$ \\
\hline 11 & Leaf: collar & $\begin{array}{l}\text { absent } \\
\text { present }\end{array}$ & $\begin{array}{c}\text { Nil } \\
47\end{array}$ \\
\hline 12 & Leaf: anthocyanin colouration of collar & absent & 47 \\
\hline
\end{tabular}




\begin{tabular}{|c|c|c|c|}
\hline & & present & Nil \\
\hline 13 & Leaf: ligule & $\begin{array}{l}\text { absent } \\
\text { present }\end{array}$ & $\begin{array}{c}\mathrm{Nil} \\
47\end{array}$ \\
\hline 14 & Leaf: shape of ligule & $\begin{array}{l}\text { truncate } \\
\text { acute } \\
\text { split }\end{array}$ & $\begin{array}{c}\mathrm{Nil} \\
4 \\
43\end{array}$ \\
\hline 15 & Leaf: color of ligule & $\begin{array}{l}\text { white/green } \\
\text { light purple } \\
\text { purple }\end{array}$ & $\begin{array}{c}46 \\
1 \\
\text { Nil }\end{array}$ \\
\hline 16 & Culm: attitude & $\begin{array}{l}\text { erect } \\
\text { semi-erect } \\
\text { open } \\
\text { spreading }\end{array}$ & $\begin{array}{c}13 \\
29 \\
3 \\
2 \\
\end{array}$ \\
\hline 17 & Flag leaf: attitude of blade & $\begin{array}{l}\text { erect } \\
\text { semi-erect } \\
\text { horizontal } \\
\text { deflexed }\end{array}$ & $\begin{array}{c}9 \\
38 \\
\text { Nil } \\
\text { Nil }\end{array}$ \\
\hline 18 & Spikelet: density of pubescence of lemma & $\begin{array}{l}\text { absent } \\
\text { weak } \\
\text { medium } \\
\text { strong } \\
\text { very strong }\end{array}$ & $\begin{array}{c}37 \\
6 \\
\text { Nil } \\
4 \\
\text { Nil }\end{array}$ \\
\hline 19 & Spikelet: colour of stigma & $\begin{array}{l}\text { white } \\
\text { light green } \\
\text { yellow } \\
\text { light purple } \\
\text { purple }\end{array}$ & $\begin{array}{c}45 \\
\text { Nil } \\
\text { Nil } \\
\text { Nil } \\
2\end{array}$ \\
\hline 20 & Stem: anthocyanin colouration of nodes & $\begin{array}{l}\text { absent } \\
\text { present }\end{array}$ & $\begin{array}{c}46 \\
1\end{array}$ \\
\hline 21 & $\begin{array}{l}\text { Stem : intensity of anthocyanin colouration of } \\
\text { nodes }\end{array}$ & $\begin{array}{l}\text { weak } \\
\text { medium } \\
\text { strong }\end{array}$ & $\begin{array}{c}46 \\
1 \\
\text { Nil }\end{array}$ \\
\hline 22 & Stem: anthocyanin colouration of internodes & $\begin{array}{l}\text { absent } \\
\text { present }\end{array}$ & $\begin{array}{c}46 \\
1\end{array}$ \\
\hline 23 & Lemma and Palea: colour & $\begin{array}{l}\text { straw } \\
\text { gold and gold furrows on } \\
\text { straw background } \\
\text { brown spots on straw } \\
\text { brown furrows on straw } \\
\text { brown (tawny) }\end{array}$ & $\begin{array}{c}33 \\
1 \\
\text { Nil } \\
2 \\
8\end{array}$ \\
\hline
\end{tabular}




\begin{tabular}{|c|c|c|c|}
\hline & & $\begin{array}{l}\text { reddish to light purple } \\
\text { purple spots on } \\
\text { straw/ purple furrows on } \\
\text { straw } \\
\text { purple } \\
\text { black }\end{array}$ & $\begin{array}{l}\text { Nil } \\
\text { Nil } \\
\text { Nil } \\
3\end{array}$ \\
\hline 24 & Panicle : awns & $\begin{array}{l}\text { absent } \\
\text { present }\end{array}$ & $\begin{array}{c}39 \\
8\end{array}$ \\
\hline 25 & Panicle: colour of awns (late observation) & $\begin{array}{l}\text { yellowish white } \\
\text { yellowish brown } \\
\text { brown } \\
\text { reddish brown } \\
\text { light red } \\
\text { red } \\
\text { light purple } \\
\text { purple } \\
\text { black }\end{array}$ & $\begin{array}{c}7 \\
\text { Nil } \\
\text { Nil } \\
\text { Nil } \\
\text { Nil } \\
\text { Nil } \\
\text { Nil } \\
1 \\
\text { Nil }\end{array}$ \\
\hline 26 & Panicle: presence of secondary branching & $\begin{array}{l}\text { absent } \\
\text { present }\end{array}$ & $\begin{array}{l}\mathrm{Nil} \\
47\end{array}$ \\
\hline 27 & Panicle: secondary branching & $\begin{array}{l}\text { weak } \\
\text { strong } \\
\text { clustered }\end{array}$ & $\begin{array}{l}\text { Nil } \\
47 \\
\text { Nil }\end{array}$ \\
\hline 28 & Panicle: attitude of branches & $\begin{array}{l}\text { erect } \\
\text { erect to semi-erect } \\
\text { semi-erect } \\
\text { semi-erect to spreading } \\
\text { spreading }\end{array}$ & $\begin{array}{c}\text { Nil } \\
\text { Nil } \\
10 \\
37 \\
\text { Nil }\end{array}$ \\
\hline 29 & Panicle: exsertion & $\begin{array}{l}\text { partly exserted } \\
\text { Just exserted } \\
\text { well exserted }\end{array}$ & $\begin{array}{l}\mathrm{Nil} \\
12 \\
35 \\
\end{array}$ \\
\hline 30 & Decorticated grain: colour (seed coat colour) & $\begin{array}{l}\text { white } \\
\text { light brown } \\
\text { variegated brown } \\
\text { dark brown } \\
\text { light red } \\
\text { red } \\
\text { variegated purple } \\
\text { purple } \\
\text { dark purple }\end{array}$ & $\begin{array}{c}46 \\
\text { Nil } \\
\text { Nil } \\
\text { Nil } \\
\text { Nil } \\
1 \\
\text { Nil } \\
\text { Nil } \\
\text { Nil }\end{array}$ \\
\hline 31 & Decorticated grain: aroma (Aroma test) & $\begin{array}{l}\text { absent } \\
\text { present }\end{array}$ & $\begin{array}{l}\text { Nil } \\
47\end{array}$ \\
\hline
\end{tabular}


Fig.1 Frequency distribution of important morphological characters

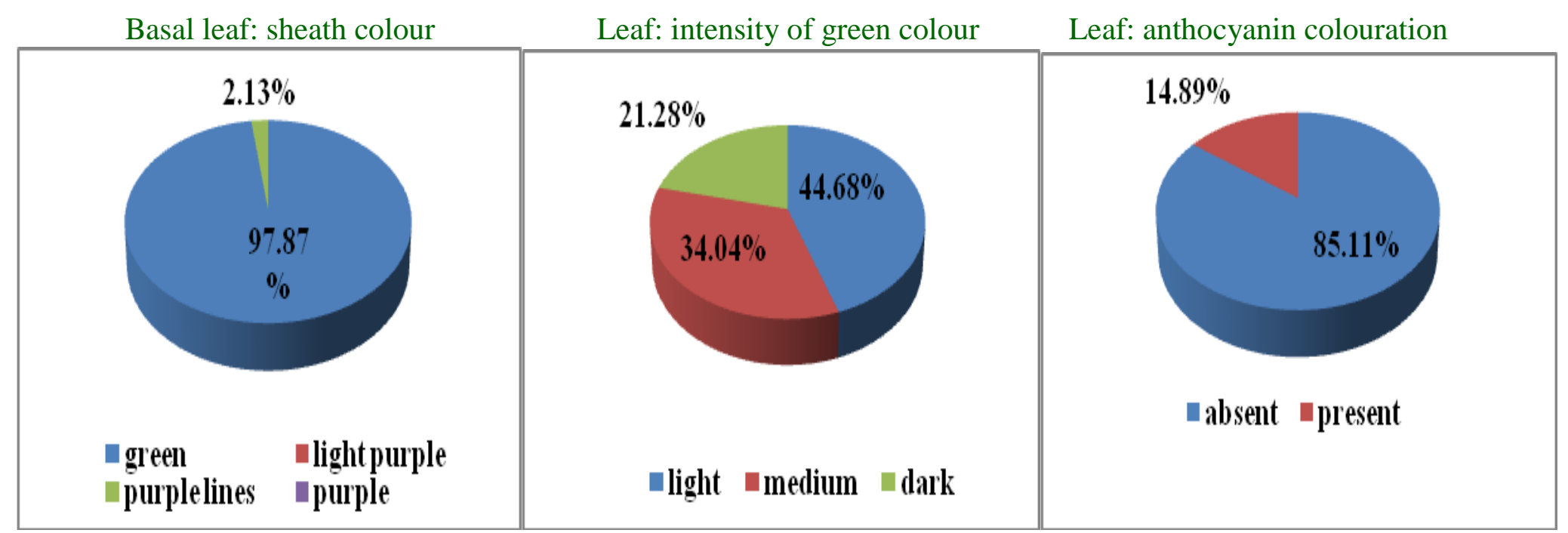

Leaf sheath: anthocyanin colouration Leaf sheath: intensity of anthocyanin colouration Leaf: pubescence of blade surface

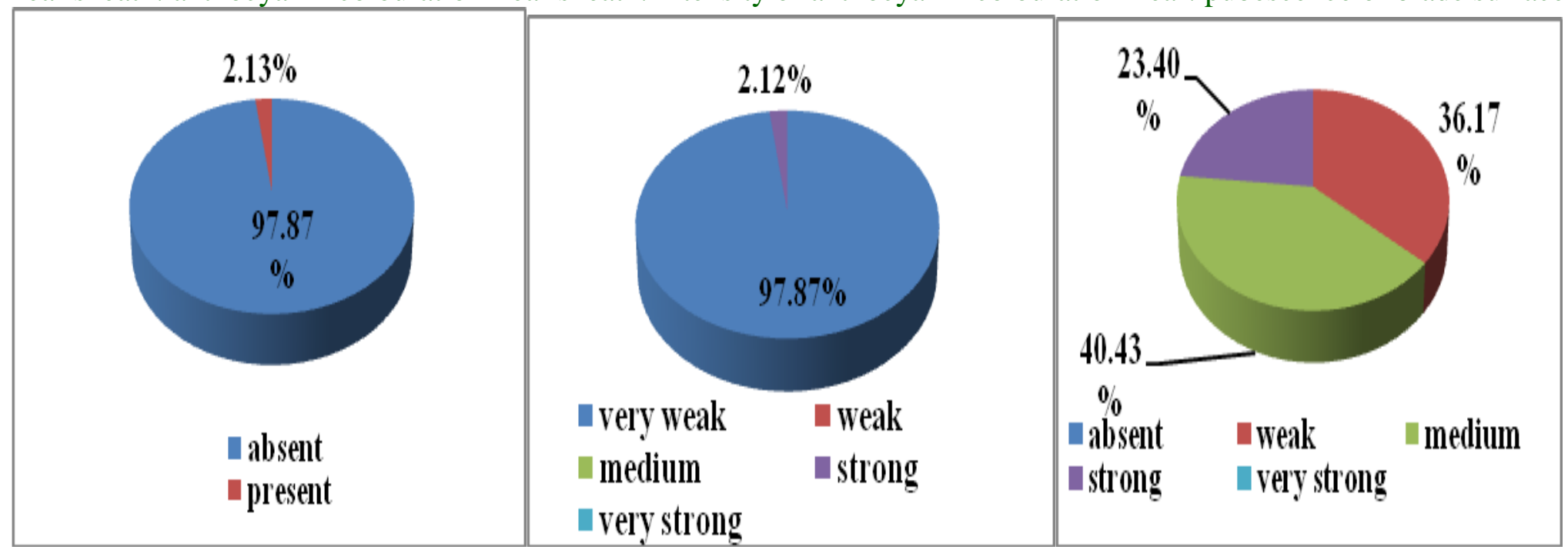




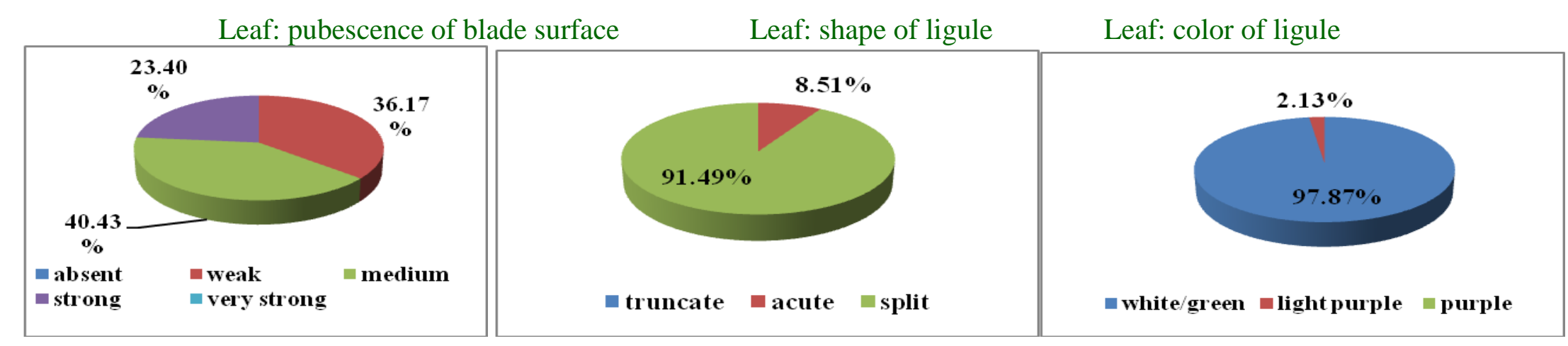

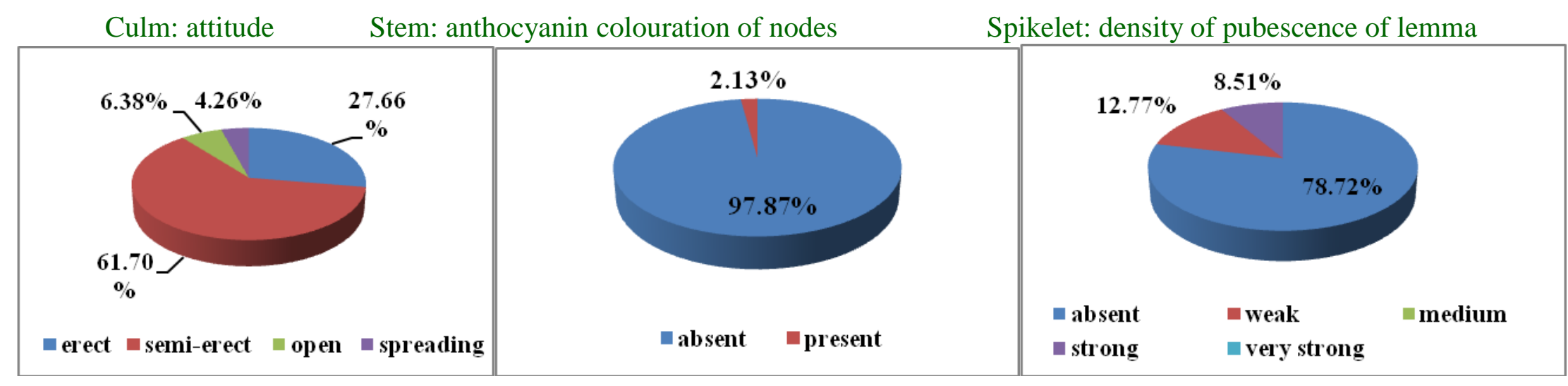

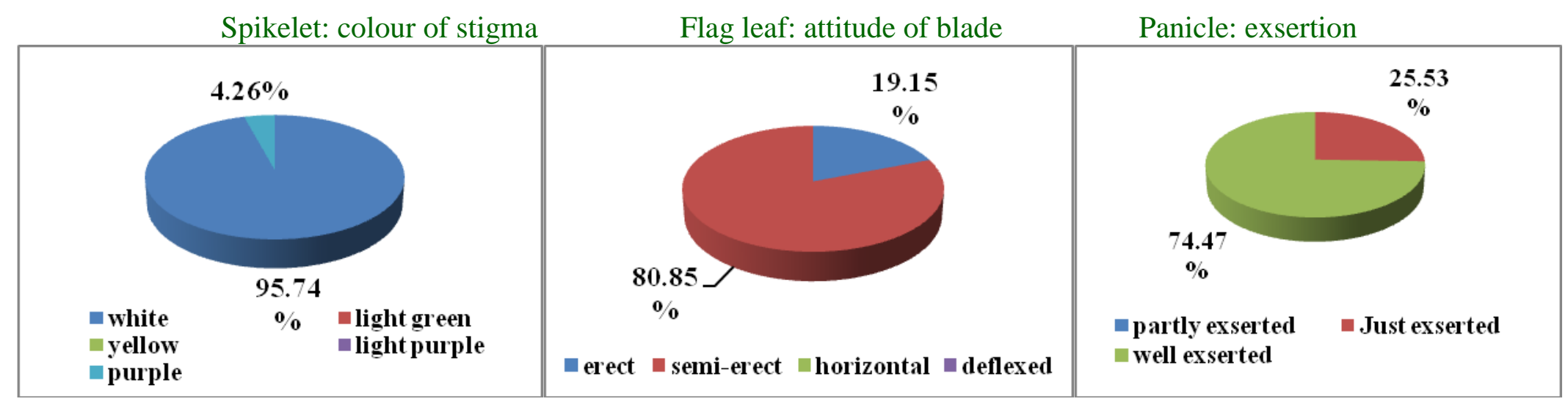




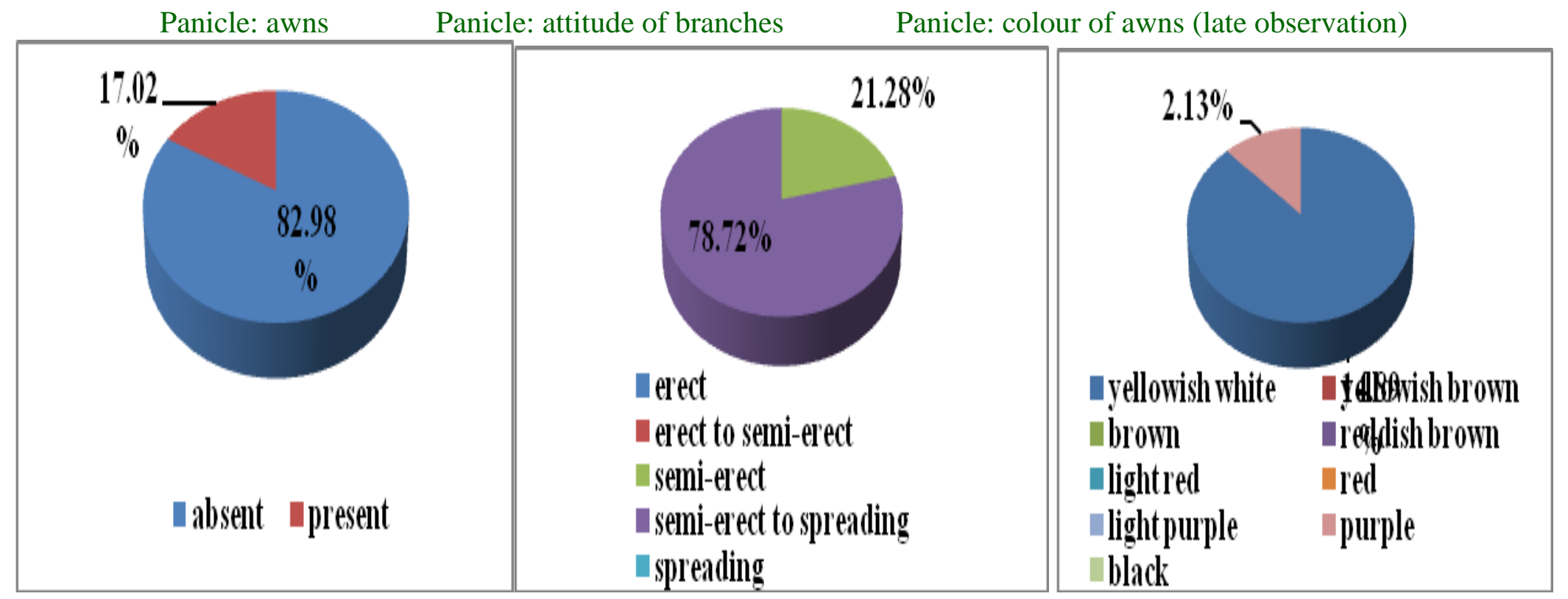

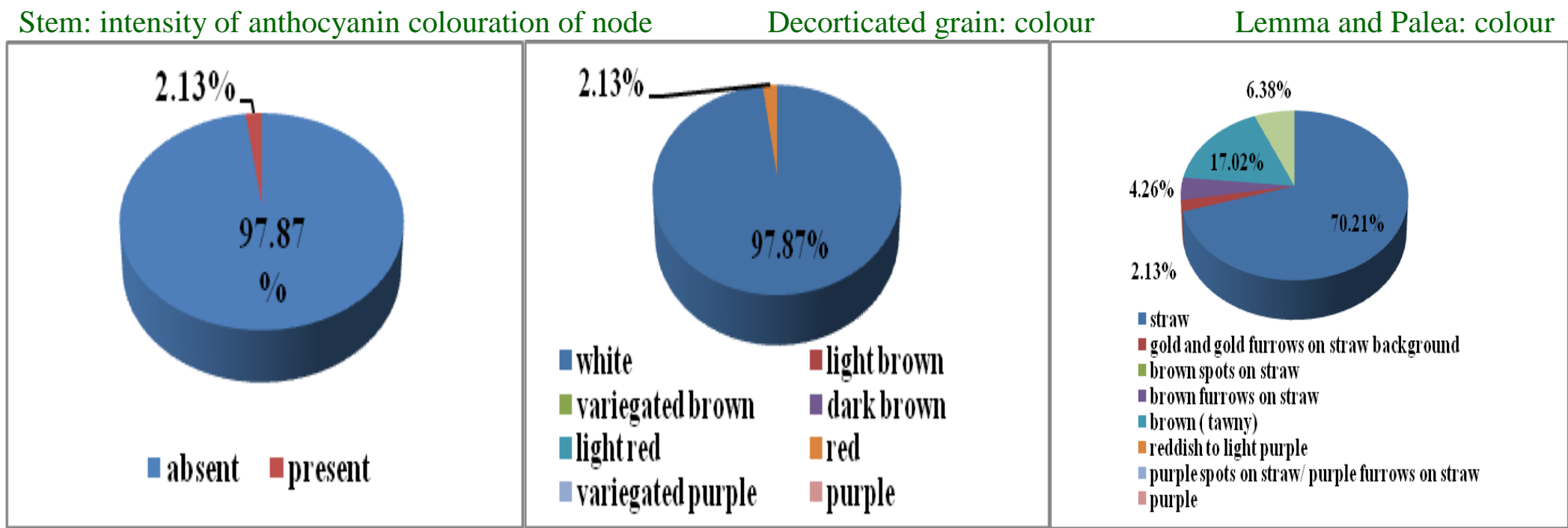


Fig.2 Frequency distribution of eight quantitative traits in rice accessions
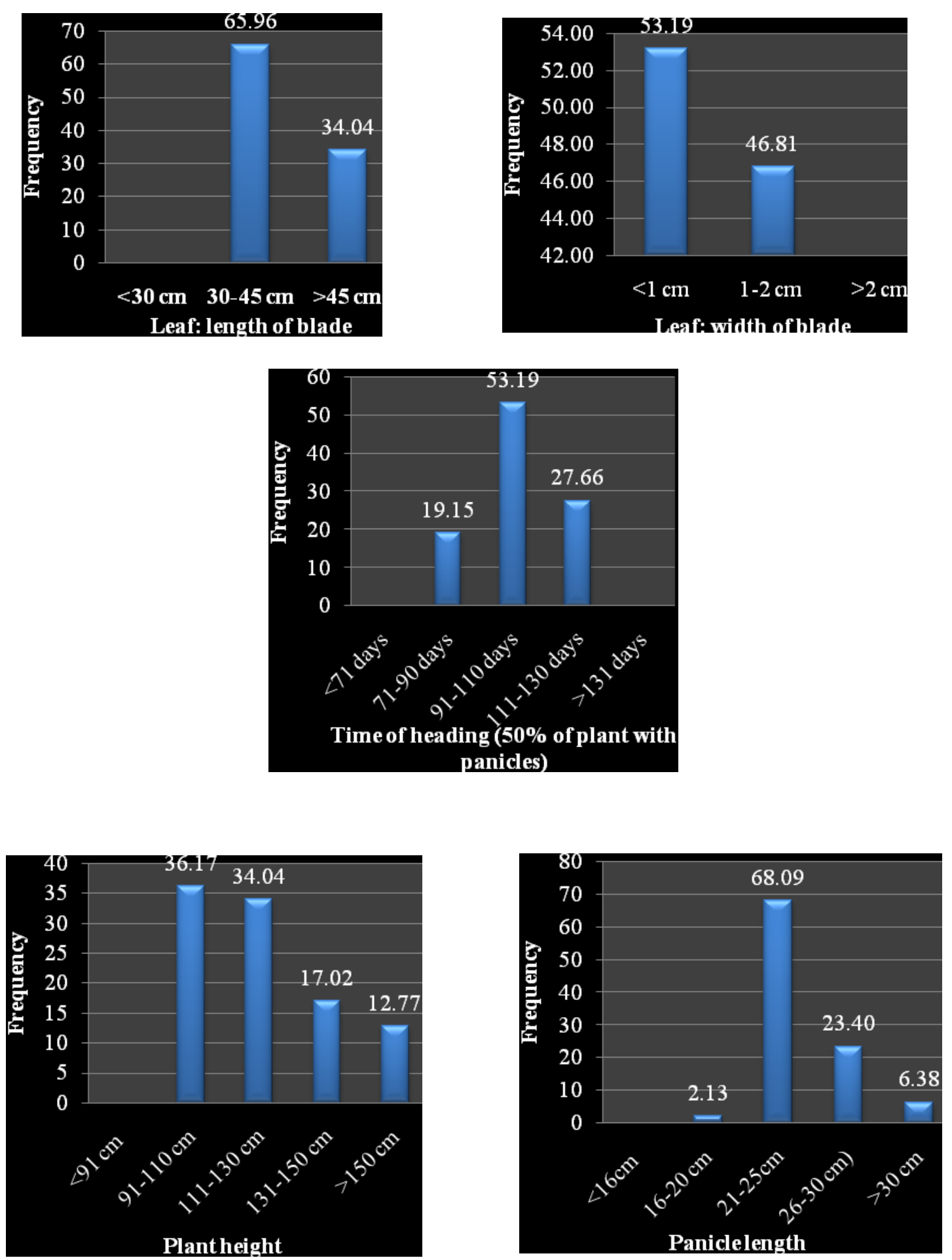

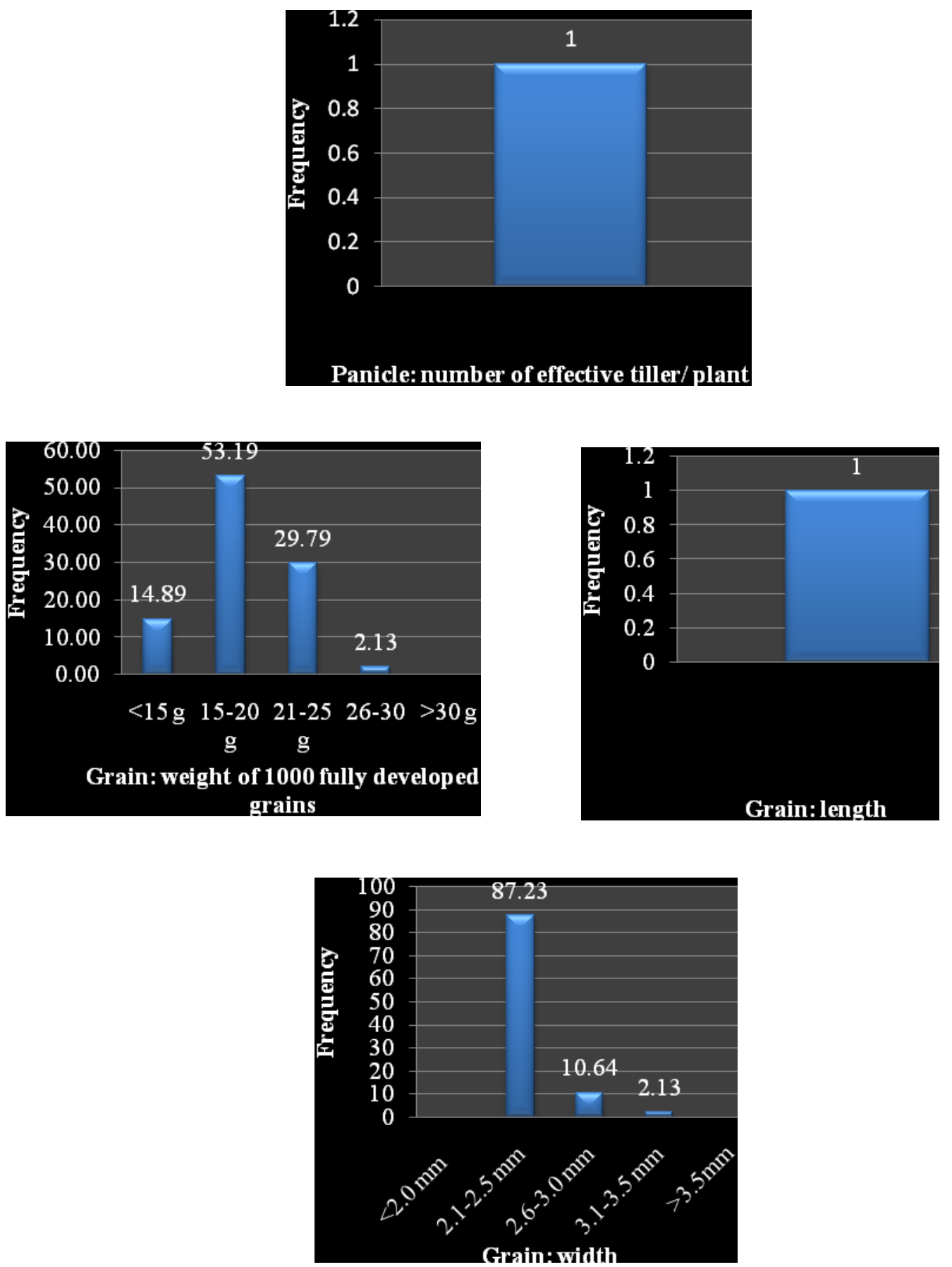

\section{Panicle length $(\mathrm{cm})$}

It exhibited reasonable amount of variation with range values of $20.80 \mathrm{~cm}$ to $33.70 \mathrm{~cm}$. The average panicle length was $25.56 \mathrm{~cm}$ long. Most of the accessions fall under the range of $26-30 \mathrm{~cm}$ panicle length. The highest panicle length was recorded in Kalanamak $(33.70 \mathrm{~cm})$. However, the minimum panicle length was recorded in HUR-917 $(20.80 \mathrm{~cm})$. Although it contributes positively yet maximum panicle length is not the only factor responsible for higher grain yield (Abbasi et al., 1995). So panicle length alone does not 
determine the high grain yield as traits such as grain size, higher number of tillers/plant, longer panicles and greater number of grains/panicle ultimately contribute to higher grain yield (Akram et al., 1994).

\section{Number of effective tillers per plant}

It is another yield attributing trait (Abbasi et $a l ., 1995)$. The range for number of effective tillers per plant varied from 3 to 9 with an overall mean of 6.74. The highest effective tillers per plant was recorded in Indira Sugandhit Dhan-1 (9) and the minimum effective tillers per plant was recorded in NDR6357 (3).

\section{0 seed weight (gm)}

It is also a yield-attributing trait (Abbasi et al., 1995). 1000 seed weight ranged from 9.40 to $26.55 \mathrm{~g}$ with an average weight of $17.96 \mathrm{~g}$. Genotype with maximum 1000 seed weight recorded in CN 1268-5-7 (26.55 g) and the minimum 1000 seed weight was recorded in Badshahbhog $(9.40 \mathrm{~g})$.

\section{Grain length (cm)}

Grain length is an important quality parameter. Rice grain can be classified as extra-long, long, medium and short (Akram et al., 1994). Grain length ranged from 0.58 to 1.07 with a mean performance of $0.78 \mathrm{~cm}$.

The maximum grain length (1.07) recorded for HUR 1307 and minimum grain length (0.58) was recorded for HUR 1309.

\section{Grain width (cm)}

Grain width ranged from 0.21 to 0.31 with a mean performance of $0.24 \mathrm{~cm}$. The maximum grain width (0.31) recorded for R-1521-9506-843-1 and minimum grain width (0.21) was recorded for CR 2938-6.

\section{References}

Abbasi, F.M., Sagar, M.A., Akram, M. and Ashraf, M. 1995. Agronomic and quality traits of some elite rice genotypes. Pakistan Journal of Scientific and Industrial Research 38: 348-350.

Akram, M., Abbasi, F.M., Sagar, M.A. and Ashraf, M. 1994. Increasing rice productivity through better utilization of germplasm. pp: 107-14. In: Proc. of a Nat. Semi. on Genetic Resources of Cereals and their Utilization. Islamabad, Pakistan.

Ali, S.S., Jafri, S.J.H., Khan, T.Z., Mahmood, A. and Butt, M.A. 2000. Heritability of yield and yield components of rice. Pakistan Journal of Agricultural Research 16: 89-91.

Cheema, A.A., Awan, M.A. and Iqbal, J. 1987. Improvement of plant height architecture in basmati rice. Pakistan Journal of Agricultural Research 8: 371-4.

Emani, C., Jiang, Y., Miro, B., Hall, T.C. and Kohali, A. 2008. Transgenic cereals and forage grasses. In: Compendium of transgenic crop plants (eds) Kole. C. and Hall, T.C. 1:1- 234.

\section{How to cite this article:}

Nidhi Kujur, Sandeep Bhandarker, Yogita Shrivas and Alice Tirkey. 2017. Assessment of Variability of Aromatic Rice Using Agro-Morphological Characterization. Int.J.Curr.Microbiol.App.Sci. 6(11): 1835-1846. doi: https://doi.org/10.20546/ijcmas.2017.611.219 